\title{
Characterization of diversity among 3 squirreltail taxa
}

\author{
T.A. JONES*, D.C. NIELSON, J.T. ARREDONDO, AND M.G. REDINBAUGH
}

T.A. Jones and D.C. Nielson, Research Geneticist and Entomologist, USDA-ARS Forage and Range Research Laboratory, Utah State University, Logan, Utah 84322-6300; former Research Associate, J.T. Arredondo, Departamento de Ingenieria Ambiental y Manejo de Recursos Naturales. Instituto Potosino de Investigacion Cientifica y Tecnologica (IPICYT) Rio Kennedy 205, Col. Bellas Lomas San Luis Potosi, SLP, CP78210 Mexico; M.G. Redinbaugh, Research Plant Physiologist, USDA-ARS, Corn and Soybean Research, Ohio Agricultural and Research Development Center, Selby Hall, 680 Madison Ave., Wooster, Ohio 44691-4096.

\section{Abstract}

Squirreltail (Elymus elymoides, $E$. multisetus) is a complex of 5 taxa whose systematic interrelationships are uncertain. Our objectives were to determine whether the 3 taxa studied here, Elymus elymoides ssp. elymoides, E. elymoides ssp. brevifolius, and $E$. multisetus, can be distinguished by several ecological and physiological traits and whether geographical origin is correlated with these traits across accessions within taxa. A multivariate principal component analysis of materials collected in the 10 contiguous western states successfully distinguished taxa, but no pair of the 3 taxa appeared to be more ecologically similar than any other pair. Elymus elymoides ssp. elymoides, which prevails in the semi-arid cold desert, was shortest and exhibited the lowest total plant dry-matter, earliest phenology, and lowest seed mass. Elymus elymoides ssp. brevifolius, which prevails in the Rocky Mountains, exhibited slowest emergence, highest specific root length, lowest nitrate reductase activity, and lowest root-to-shoot ratio. Elymus multisetus, which is most common in areas with relatively warm springs, exhibited fastest emergence (particularly from deep seeding), greatest root length, and greatest root-toshoot ratio. Elymus elymoides ssp. brevifolius accessions clustered into 3 groups: late-maturing high-seed mass accessions originating in Colorado, New Mexico, and Arizona (Group A), earlymaturing low-seed mass accessions originating in Colorado and Utah (Group B), and intermediate-maturing low-seed mass accessions originating in the Snake River Plain of southern Idaho (Group C). The ecologically distinct subspecies and groups within ssp. brevifolius are indicative of the highly ecotypic nature of the squirreltails, suggesting that restoration practitioners should match site with genetically and ecologically appropriate plant material for these species.

Key Words: Elymus elymoides, genetic variation, plant autecology, Sitanion hystrix

The squirreltails (Elymus elymoides [Raf.] Swezey and E. multisetus [J.G. Smith] Burtt-Davy) are increasingly important grasses for restoring rangeland communities on disturbed sites in the Intermountain Region of western North America. Systematists generally recognize up to 5 squirreltail taxa (Wilson 1963), which we refer to in this paper as elymoides, brevifolius, californicus, hordeoides, and multisetus. These taxa have been recognized in

This research was supported by the Utah Agricultural Experiment Sation, Utah State University, Logan, Utah 84322-4810. Approved as journal paper no. 7386. *Corresponding author (tomjones@cc.usu.edu).

Manuscript accepted 10 Oct. 02.

\section{Resumen}

"Squirreltail (Elymus elymoides, E. multisetus) es un complejo de 5 taxas cuyas interrelaciones sistemáticas son inciertas. Nuestros objetivos fueron determinar si las 3 taxas estudiadas aquí Elymus elymoides ssp. elymoides, E. elymoides ssp. brevifolius, y $E$. multisetus, pueden ser distinguidas por varias características ecológicas y fisiológicas y si el origen geográfico esta correlacionado con estas características a través de las accesiones dentro de la taxa. Un análisis multivariado de componentes principales de los materiales colectados en los 10 estados contiguos del oeste distinguió en forma exitosa la taxa, pero ningún par de las tres taxas pareció ser mas ecológicamente similar que cualquier otro par. Elymus elymoides ssp. elymoides, el cual prevalece en el desierto frío semiárido, fue el más corto y mostró la menor materia seca por planta, la fisiología más temprana y la menor biomasa de semilla. Elymus elymoides ssp. brevifolius, que prevalece en las Montañas Rocallosas presento la emergencia mas lenta, la mayor longitud especifica de raíz, la mas baja actividad de nitrato reductasa y la relación más baja de tallo:raíz. Elymus multisetus, que es mas común en áreas con primaveras relativamente calientes, mostró la emergencia más rápida (particularmente en siembras profundas), la mayor longitud de raíz y la mayor relación tallo:raíz. Las accesiones de Elymus elymoides ssp. brevifolius se agruparon en tres grupos: accesiones de madurez tardía-alta biomasa de semilla originarias de Colorado, New Mexico y Arizona (Grupo A), accesiones de madurez temprana -baja biomasa de semilla originarias de Colorado y Utah (Grupo B) y un grupo de accesiones de madurez intermedia-baja biomasa de semilla originarias del Snake River Plain del sudeste de Idaho (Group C). Las subespecies y grupos ecológicamente distintos dentro de ssp. brevifolius son indicativos de la naturaleza altamente ecotípica de los "Squirreltails, sugiriendo que los que practican la restauración de pastizales deben aparejar el sitio con un el material vegetal genética y ecológicamente apropiado de estas especies.

both Sitanion and in Elymus, with the latter being the currently preferred classification (Barkworth et al. 1983). However, rank of the taxa varies with taxonomic treatment.

There seems to be little dissension regarding the retention of 2 taxa in E. elymoides, namely ssp. elymoides and ssp. californicus. Wilson (1963) mentioned the marked similarity of their karyotypes. Also, M.E. Barkworth and J.J.N. Campbell (pers. comm. 2000) noted that they appear to hybridize when sympatric.

Taxonomic treatments have varied in their handling of specimens keying to brevifolius and hordeoides in Wilson's (1963) 
treatment. Brevifolius was treated as a separate species by Wilson (1963) ( $S$. longifolium J.G. Smith), reluctantly treated as a separate species by Holmgren and Holmgren (1977), treated as a subspecies of E. elymoides (ssp. brevifolius) by M.E. Barkworth and J.J.N. Campbell (2000 pers. comm.), and unrecognized as a separate taxon by Hitchcock (1950) and Arnow (1993). Hordeoides has been treated as a separate species by Wilson (1963) (S. hordeoides Suksdorf) or as part of a species including elymoides, californicus, and brevifolius by Holmgren and Holmgren (1977) and by M.E. Barkworth and J.J.N. Campbell (pers. comm.).

Some systematists readily recognize multisetus as worthy of specific rank ( $E$. multisetus [J.G. Smith] Burtt-Davy $=S$. jubatum J.G. Smith) (Hitchcock 1950, Wilson 1963, Barkworth et al. 1983), while others do so only reluctantly (Holmgren and Holmgren 1977). Wilson (1963) noted that the karyotype of multisetus was the most distinctive of the 5 squirreltail taxa. He reported extensive introgressive hybridization between multisetus and elymoides in southeastern California and southern Nevada, though not in other locales where these 2 taxa are sympatric. Holmgren and Holmgren (1977) suggested that a reasonable approach would be amalgamation of all 5 taxa into a single species.

Wilson (1963) provides a reliable key that easily separates the 5 taxa based on floral appendages. We have used it to identify over 100 accessions in our collection, which includes representatives of all taxa except hordeoides. Our objective was to determine how 3 taxa, multisetus, brevifolius, and elymoides, compare for traits relating to seedling establishment, leaf and root morphology, and phenology because such traits may be correlated with adaptation to particular range sites. We also wished to determine the degree of separation or overlap between the taxa based on these traits and to gather any insights from the relationship between performance and geographical origin of the accessions.

\section{Materials and Methods}

\section{Data set 1}

Twenty-one of the 27 accessions (Tables 1,2 ) in data set 1 originated from USDA-NRCS Plant Materials Centers in Aberdeen, Ida. and Bridger, Mont., or the Upper Colorado Environmental Plant Center in Meeker, Colo.. Two accessions

Table 1. Means for 1 californicus, 17 elymoides, 5 brevifolius, and 4 multisetus squirreltail accessions in data set 1 for 8 traits in a 25-day greenhouse trial.

\begin{tabular}{|c|c|c|c|c|c|c|c|c|c|}
\hline Accession & Collection location & $\begin{array}{c}\text { Days to } \\
\text { emergence }\end{array}$ & $\begin{array}{l}\text { Leaf length } \\
\text { (10 days } \\
\text { post-plant) }\end{array}$ & $\begin{array}{l}\text { Total plant } \\
\text { dry-matter }\end{array}$ & $\begin{array}{l}\text { Root-to- } \\
\text { shoot } \\
\text { ratio }\end{array}$ & $\begin{array}{l}\text { Leaf } \\
\text { area }\end{array}$ & $\begin{array}{l}\text { Specific } \\
\text { leaf area }\end{array}$ & $\begin{array}{l}\text { Root } \\
\text { length }\end{array}$ & $\begin{array}{c}\text { Specific } \\
\text { root } \\
\text { length }\end{array}$ \\
\hline & & (no.) & $(\mathrm{mm})$ & $\left(\mathrm{mg} \mathrm{plant}^{-1}\right)$ & $\left(\mathrm{mg} \mathrm{mg}^{-1}\right)$ & $\begin{array}{l}\left(\mathrm{mm}^{2}\right. \\
\left.\text { plant }^{-1}\right)\end{array}$ & $\begin{array}{l}\left(\mathrm{mm}^{2}\right. \\
\left.\mathrm{mg}^{-1}\right)\end{array}$ & $\begin{array}{c}(\mathrm{mm} \\
\left.\text { plant }^{-1}\right)\end{array}$ & $\left(\mathrm{mm}^{-1}\right)$ \\
\hline \multicolumn{10}{|l|}{ californicus } \\
\hline \multicolumn{10}{|l|}{ elymoides } \\
\hline Acc: 1107 & sec 32 T22N R22E, Lemhi Co., Ida. & 5.4 & 65 & 9.56 & 0.424 & 148 & 29.1 & 916 & 317 \\
\hline Acc: 1108 & sec 36 T4N R26E, Butte Co., Ida. & 6.3 & 61 & 9.57 & 0.315 & 168 & 29.4 & 698 & 316 \\
\hline Acc: 1109 & sec 11 T4N R26E, Butte Co., Ida. & 6.0 & 58 & 9.26 & 0.306 & 182 & 31.9 & 652 & 324 \\
\hline Acc: 1110 & sec 26 T4N R26E, Butte Co., Ida. & 5.8 & 58 & 6.98 & 0.516 & 110 & 31.0 & 687 & 289 \\
\hline Acc: 1111 & sec 11 T4N R26E, Butte Co., Ida. & 6.2 & 58 & 8.38 & 0.442 & 158 & 33.5 & 853 & 337 \\
\hline Acc: 1112 & sec 11 T4N R27E, Butte Co., Ida. & 5.1 & 67 & 9.79 & 0.365 & 175 & 31.0 & 838 & 330 \\
\hline Acc: 1113 & 1737 m, Custer Co., Ida. & 5.3 & 74 & 8.85 & 0.423 & 157 & 31.3 & 1057 & 410 \\
\hline Acc: 1114 & Morse Creek, Custer Co., Ida. & 6.2 & 54 & 7.14 & 0.291 & 116 & 27.7 & 641 & 410 \\
\hline Acc: 1115 & Leaton Gulch, Custer Co., Ida. & 6.2 & 62 & 9.57 & 0.405 & 167 & 32.6 & 717 & 270 \\
\hline Acc: 1116 & Bradbury Flat, Custer Co., Ida. & 6.0 & 64 & 9.56 & 0.335 & 178 & 33.8 & 668 & 275 \\
\hline Acc: 1117 & Round Valley, Custer Co., Ida. & 5.6 & 62 & 10.18 & 0.354 & 182 & 32.9 & 814 & 322 \\
\hline Acc: 1124 & Squaw Butte, Harney Co., Ore. & 6.1 & 60 & 10.27 & 0.359 & 150 & 25.2 & 960 & 368 \\
\hline PI 619489 & Whitehall, Mont. & 5.4 & 63 & 8.86 & 0.427 & 142 & 29.0 & 830 & 323 \\
\hline PI 619491 & Big Piney, Wyo. & 5.6 & 60 & 10.33 & 0.352 & 191 & 32.1 & 711 & 273 \\
\hline PI 619555 & Warren, Mont. & 6.2 & 57 & 9.36 & 0.285 & 174 & 31.7 & 629 & 298 \\
\hline PI 619561 & Big Piney, Wyo. & 5.8 & 60 & 9.69 & 0.436 & 167 & 32.0 & 821 & 306 \\
\hline 9019219 & btwn Worland \& Ten Sleep, Wyo. & 5.8 & 64 & 10.15 & 0.325 & 214 & 35.2 & 667 & 284 \\
\hline mean & & $5.8 \mathrm{~b}^{\#}$ & $62 \mathrm{~b}$ & $9.26 \mathrm{c}$ & $0.374 \mathrm{~b}$ & $163 \mathrm{~b}$ & 31.1 a & $774 \mathrm{~b}$ & 321 a \\
\hline \multicolumn{10}{|l|}{ brevifolius } \\
\hline Acc: 1123 & btwn Prairie City \& Dixie Pass, Ore. & 5.7 & 70 & 12.44 & 0.358 & 197 & 27.6 & 1017 & 343 \\
\hline Acc: 1130 & Savageton, Wyo. & 6.4 & 71 & 9.35 & 0.280 & 157 & 28.0 & 700 & 376 \\
\hline PI 531605 & $\begin{array}{l}\text { btwn N. LaVeta Pass } \\
\text { \& Gardner, Colo. }\end{array}$ & 7.0 & 56 & 10.50 & 0.267 & 154 & 23.8 & 794 & 368 \\
\hline 9040187 & Wet Mountains, Custer Co., Colo. & 7.4 & 49 & 10.75 & 0.305 & 158 & 25.0 & 836 & 361 \\
\hline 9040189 & Buford, Rio Blanco Co., Colo. & 6.3 & 65 & 12.10 & 0.333 & 210 & 29.7 & 943 & 332 \\
\hline mean & & $6.6 \mathrm{a}$ & $62 \mathrm{~b}$ & $11.03 \mathrm{~b}$ & $0.309 c$ & $175 \mathrm{~b}$ & $26.8 \mathrm{~b}$ & 858 b & $356 \mathbf{a}$ \\
\hline \multicolumn{10}{|l|}{ multisetus } \\
\hline Acc: 1132 & Paradise Valley, Nev. & 4.8 & 85 & 16.60 & 0.483 & 269 & 31.2 & 1434 & 268 \\
\hline PI 531603 & Lake Tahoe, Nev. & 4.4 & 85 & 18.48 & 0.483 & 303 & 31.0 & 1980 & 335 \\
\hline PI 531606 & Central Ferry, Wash. & 4.8 & 82 & 13.89 & 0.392 & 245 & 32.3 & 1520 & 393 \\
\hline PI 619466 & Redlands, Lassen Co., Cal. & 5.5 & 84 & 15.45 & 0.429 & 262 & 31.2 & 1161 & 278 \\
\hline mean & & $4.9 \mathrm{c}$ & $84 a$ & $16.11 \mathrm{a}$ & 0.447 a & 270 a & $31.4 \mathrm{a}$ & 1524 a & 319 a \\
\hline
\end{tabular}

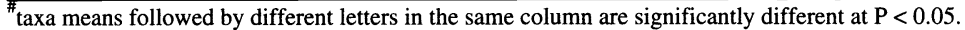


Table 2. Means for 1 californicus, 17 elymoides, 5 brevifolius, and 4 multisetus squirreltail accessions in data set 1 for 5 traits in field and greenhouse trials.

\begin{tabular}{|c|c|c|c|c|c|}
\hline \multirow[t]{2}{*}{ Accession } & \multirow{2}{*}{$\frac{\text { Heading date }}{\text { (days after } 30 / 4 / 95)}$} & \multirow{2}{*}{$\frac{\text { Seed mass }}{\left(\mathrm{mg} \mathrm{seed}^{-1}\right)}$} & \multicolumn{2}{|c|}{ Emergence index } & \multirow{2}{*}{$\begin{array}{c}\text { Nitrate } \\
\text { reductase activity } \\
\text { (per mg protein) }\end{array}$} \\
\hline & & & $(20 \mathrm{~mm})$ & $(60 \mathrm{~mm})$ & \\
\hline \multicolumn{6}{|l|}{ californicus } \\
\hline PI 531604 & 29 & 4.14 & 6.36 & 3.64 & 7.66 \\
\hline \multicolumn{6}{|l|}{ elymoides } \\
\hline Acc: 1107 & 15 & 3.27 & 6.71 & 3.01 & 7.83 \\
\hline Acc: 1108 & 27 & 2.67 & 6.54 & 2.01 & 7.34 \\
\hline Acc:1109 & 15 & 2.71 & 6.62 & 3.03 & 7.01 \\
\hline Acc: 1110 & 31 & 2.95 & 6.51 & 2.34 & 5.38 \\
\hline Acc: 1111 & 19 & 3.02 & 6.31 & 2.80 & 7.17 \\
\hline Acc: 1112 & 24 & 2.47 & 6.74 & 2.90 & 6.52 \\
\hline Acc: 1113 & 31 & 2.94 & 7.21 & 3.38 & 6.03 \\
\hline Acc:1114 & 17 & 3.07 & 6.36 & 3.50 & 7.50 \\
\hline Acc: 1115 & 33 & 3.43 & 6.67 & 4.36 & 8.48 \\
\hline Acc: 1116 & 33 & 3.49 & 6.83 & 4.40 & 9.46 \\
\hline Acc: 1117 & 36 & 3.33 & 7.43 & 4.80 & 9.13 \\
\hline Acc: 1124 & 36 & 3.44 & 6.64 & 2.93 & 6.68 \\
\hline PI 619489 & 31 & 3.26 & 5.71 & 1.14 & 7.34 \\
\hline PI 619491 & 29 & 3.48 & 6.44 & 3.40 & 8.48 \\
\hline PI 619555 & 33 & 3.00 & 6.60 & 2.82 & 7.83 \\
\hline PI 619561 & 27 & 2.86 & 6.56 & 3.41 & 8.64 \\
\hline 9019219 & 29 & 4.07 & 6.18 & 4.32 & 8.64 \\
\hline mean & $27 b^{\#}$ & $3.14 \mathrm{~b}$ & $6.59 \mathrm{a}$ & $3.21 \mathrm{ab}$ & $7.62 \mathrm{a}$ \\
\hline \multicolumn{6}{|l|}{ brevifolius } \\
\hline Acc: 1123 & 47 & 3.94 & 5.67 & 3.73 & 3.91 \\
\hline Acc:1130 & 29 & 3.98 & 5.92 & 3.94 & 6.85 \\
\hline PI 531605 & 46 & 6.83 & 5.05 & 3.40 & 4.57 \\
\hline 9040187 & 59 & 6.32 & 5.62 & 3.43 & 5.54 \\
\hline 9040189 & 45 & 5.51 & 5.46 & 2.94 & 5.87 \\
\hline mean & $45 a$ & $5.32 \mathrm{a}$ & $5.54 \mathrm{~b}$ & $3.49 \mathrm{~b}$ & $5.35 \mathrm{~b}$ \\
\hline \multicolumn{6}{|l|}{ multisetus } \\
\hline Acc:1132 & 42 & 5.29 & 6.58 & 4.03 & 9.62 \\
\hline PI 531603 & 50 & 6.33 & 6.10 & 4.24 & 8.64 \\
\hline PI 531606 & 47 & 4.89 & 7.30 & 4.25 & 8.15 \\
\hline PI 619466 & 33 & 4.69 & 7.25 & 3.63 & 8.15 \\
\hline mean & $43 a$ & $5.30 \mathrm{a}$ & $6.81 \mathrm{a}$ & $4.04 \mathrm{a}$ & 8.64 a \\
\hline
\end{tabular}

\#taxa means followed by different letters in the same column are significantly different at $\mathrm{P}<0.05$.

were obtained from USDA-ARS, i.e., W6 22031 (David C. Ganskopp, Burns, Ore.) and W6 20963 (James A. Young, Reno, Nev.). The 4 remaining accessions (PI 531603 through PI 532606), obtained from the National Plant Germplasm System, were originally from the collection of the late D.R. Dewey of our laboratory. We determined the taxon of each accession using the dichotomous key provided by Wilson (1963) that distinguishes the taxa based on number and bifurcation of awns. Seed samples of these accessions are deposited in the National Plant Germplasm System at the USDA-ARS Western Regional Plant Introduction Station in Pullman, Wash. (http://www.ars_grin.gov/npgs).

Data were collected from evaluations in the field and 4 greenhouse trials. The field evaluation was established on 2-3 Sept. 1993 at Greenville Farm, North Logan, Ut. $\left(41^{\circ} 45^{\prime} 59^{\prime \prime} \mathrm{N}, 111^{\circ} 48^{\prime \prime} 34^{\prime \prime} \mathrm{W}\right)$ on a Millville silt loam (coarse-silty, carbonatic, mesic Typic Rendolls; 2-4\% slope).
Accessions were established as field transplants on $0.5-\mathrm{m}$ centers in a $7 \times 7$ plant block. Each block was filled with 49 plants unless fewer were available. Because the blocks were not replicated, data collected from this trial were only for 2 traits of high heritability, which were heading date (the number of days after 30 Apr. 1995 that the majority of the plants in a plot had at least 1 spike emerge from the boot) and seed mass (mg seed ${ }^{-1}$ averaged across 1994 and 1995 harvests). Seed harvested from these blocks was used to conduct a seedling growth trial in the greenhouse, 2 depth-of-seeding trials, and a nitrate reductase activity assay in the greenhouse. Because outcrossing in squirreltail is negligible (Jensen et al. 1990), seed harvested from such a block may be presumed to be genetically representative of the original collection.

The seedling growth trial was planted in a greenhouse maintained at $20 \pm 5^{\circ} \mathrm{C}$ on 8 Jan. 1996 in a soil consisting of 3 parts
Kidman fine sandy loam (coarse-loamy, mixed, mesic Calcic Haploxerolls): 1 part peat moss. Five seeds of an accession were planted $5 \mathrm{~mm}$ deep in $65 \times 255-\mathrm{mm}$ cone-containers. Accessions were assigned to 10 replications in a randomized complete block design. The third seedling to emerge was retained, days-toemergence was recorded, and the other seedlings were removed. Water was supplied daily with a $32 \%$ Rorison nutrient solution (Arredondo et al. 1998). Length of the first leaf was measured on day 10 . Plants were harvested on day 25 and divided into shoots and roots. Leaf area was determined with a leaf-area meter (LI3000, LI-COR, Lincoln, Neb.). Roots were recovered by gentle washing with a slow-moving stream of water. Root length was measured on fresh tissue with 'Branching' software (version 1.52 $\beta$ ) (Berntson 1992). Shoots and roots were then oven-dried at $70^{\circ} \mathrm{C}$ for 48 hours before weighing. Specific leaf area was calculated as leaf area/shoot mass, and specific root length was calculated as root length/root mass.

To measure seedling emergence, 2 greenhouse trials were conducted at $20 \pm$ $5^{\circ} \mathrm{C}$ at depths of $20 \mathrm{~mm}$ and $60 \mathrm{~mm}$. Both trials were planted in above-ground beds filled with the greenhouse soil described above. This was underlain by a gravel layer for drainage. The beds were $1.067-\mathrm{m}$ wide and furrows were $50.8-\mathrm{mm}$ apart. Fifty seeds of an accession were planted per half-length of each furrow. Another randomized accession was planted in the opposite half. Accessions were planted in a randomized complete block design with 6 replications. The $20-\mathrm{mm}$ trial was planted on 9 to 10 Dec. 1996 and seedling emergence was tallied daily. Emergence index was calculated as $\sum\left[\left(\mathrm{g}_{\mathrm{n}}-\mathrm{g}_{(\mathrm{n}-1)}\right) / \mathrm{n}\right]$, where $\left(g_{n}-g(n-1)\right)$ is the number of seedlings germinating since the previous day and $\mathrm{n}$ is the number of days since the germination trial began (Maguire 1962). Therefore, large numbers indicate fast emergence and small numbers indicate slow emergence, the opposite direction of the days-to-emergence variable in the above-mentioned seedling growth trial. The 60-mm trial was planted on 4 Feb. 1997 and conducted similarly.

High nitrate reductase activity may facilitate higher assimilation of soil nitrogen, thereby promoting seedling establishment. For the nitrate reductase assay, the 27 accessions were grown in a $20 \pm 5^{\circ} \mathrm{C}$ greenhouse as seedlings in the same soil as the depth-of-seeding evaluations. Fresh samples of leaf tissue were harvested 2 to 
4 hours after sunrise, placed directly into liquid $\mathrm{N}_{2}$, and stored at $-80^{\circ} \mathrm{C}$ until use. and extracts were made by grinding in 5 to 10 vol. of $50 \mathrm{mM}$ MOPS buffer (pH 7.5) containing $10 \mathrm{mM} \mathrm{MgCl} 2,1 \mathrm{mM}$ EDTA, $0.1 \%$ Triton X-100, $2.5 \mathrm{mM}$ DTT, $1 \mathrm{mM}$ PMSF, $10 \mu \mathrm{M}$ leupeptin, and $10 \mu \mathrm{M}$ chymostatin. After centrifugation of the extracts at $12,000 \mathrm{~g}$ for $4 \mathrm{~min}$, the supernatant was transferred to a fresh tube and used immediately to assay total NADH:nitrate reductase activity according to Redinbaugh et al. (1996). Assays were performed in a $200-\mu$ l volume containing $50 \mathrm{mM}$ MOPS, $10 \mathrm{mM} \mathrm{K}$-phosphate buffer (pH 7.5) containing $13 \mathrm{mM} \mathrm{KNO}_{3}$, $500 \mu \mathrm{M}$ NADH, and $10 \mu \mathrm{M}$ FAD. Soluble protein in the extracts was determined using a dye-binding assay (Redinbaugh and Campbell 1985).

\section{Data set 2}

For the second data set, data were collected from a field evaluation and a greenhouse seedling growth trial. Forty-seven accessions (Table 3) were established as field transplants on 3-4 Sept. 1996 at Evans Farm, Millville, Ut. (41 $41^{\circ} 39^{\prime \prime} \mathrm{N}$ $\left.111^{\circ} 49^{\prime} 58^{\prime \prime} \mathrm{W}\right)$ on a Nibley silty clay loam (fine, mixed mesic Aquic Argiustolls; 0$3 \%$ slope). All 47 accessions were collected from their native sites in 1995 . The planting design was similar to data set 1 . Heading date (the mean number of days after 30 Apr. 1997/1998 that the majority Frozen tissue was powdered in liquid $\mathrm{N}_{2}$

of the plants in a plot had at least 1 spike emerge from the boot), seed mass (the mean mg seed ${ }^{-1}$ across 1997/1998), and plant height (mean across 1997/1998) were measured on these plots. Seed harvested from these blocks was used to conduct a seedling growth trial in the greenhouse as for data set 1 .

The seedling growth trial was planted in a greenhouse maintained at $20 \pm 5^{\circ} \mathrm{C}$ on 12 Mar. 1999 in the same design and soil as used in data set 1 . Water was supplied without nutrient solution. Days-to-emergence of the third seedling was recorded and its leaf length was measured 17 days after planting. The plants were harvested 14 Apr. (replications 1 to 3), 15 Apr. (replications 4 to 8), and 16 Apr. (replications 9 to 10) and divided into shoots and roots. For data set 2, we used a Comair root length scanner (Commonwealth Aircraft Corp. Ltd., Melbourne, Australia) to measure root length of fresh tissue that had been stored in refrigerated vials of water. This greatly expedited the process compared to the technique used for data set 1 . After scanning, shoots and roots were oven-dried at $70^{\circ} \mathrm{C}$ for 48 hours before weighing. Specific root length was calculated as root length/root mass.

\section{Statistical analysis}

For each trait, differences between means of any 2 taxa were tested for deviation from zero using a t-test at $\alpha=0.05$. Values for all accessions were standard-

Table 3. Loadings for the first 2 principal components in data sets 1 (13 traits) and 2 ( 9 traits).

\begin{tabular}{lrr}
\hline \hline & \multicolumn{2}{c}{ Principal component } \\
\cline { 2 - 3 } Trait & 1 & 2 \\
\hline Data set 1 & \\
Days to emergence & -0.563 & -0.635 \\
Leaf length & 0.818 & 0.339 \\
Total plant dry-matter & 0.968 & 0.018 \\
Root-to-shoot ratio & 0.437 & 0.526 \\
Leaf area & 0.903 & 0.227 \\
Specific leaf area & 0.055 & 0.854 \\
Root length & 0.924 & 0.059 \\
Specific root length & -0.040 & -0.517 \\
Heading date & 0.655 & -0.552 \\
Seed mass & 0.702 & -0.593 \\
Germination index $(20 \mathrm{~mm})$ & 0.028 & 0.791 \\
Germination index $(60 \mathrm{~mm})$ & 0.477 & 0.163 \\
Nitrate reductase activity & 0.222 & 0.749 \\
Data set 2 & & \\
Days to emergence & & -0.882 \\
Leaf length & 0.353 & 0.921 \\
Total plant dry-matter & 0.082 & 0.824 \\
Root-to-shoot ratio & 0.512 & 0.395 \\
Root length & -0.754 & 0.788 \\
Specific root length & 0.441 & -0.654 \\
Heading date & 0.302 & 0.008 \\
Plant height & 0.912 & 0.001 \\
Seed mass & 0.905 & 0.291 \\
\hline
\end{tabular}

ized to unit variance for each trait before multivariate analysis. Thirteen and 9 orthogonal principal components, the number of variables in each data set, were generated for data sets 1 and 2, respectively (Morrison 1976). Because a large proportion of the total variance was accounted for by the first 2 principal components for both data sets, only the first 2 were retained. These 2 principal components were each defined by a vector of scalars, each representing a trait. These are termed the principal component loadings for Principal Component 1 and Principal Component 2, respectively. Principal Component 1 loadings are the single set of numbers, 13 in the case of data set 1 and 9 in the case of data set 2 , that best circumscribes the data set. Likewise, the Principal Component 2 loadings are the second single set of numbers that best circumscribes the variation remaining after Principal Component 1 variation is removed. We rotated principal component loadings using an orthogonal varimax rotation in PROC FACTOR (SAS Institute, Cary, NC) to maximize the amount of information included in the 2 retained principal components (Kaiser 1958). Principal component scores were calculated for each accession for each of the 2 principal components by multiplying the vector of standardized means by the vector of rotated principal component loadings. Accessions were plotted in 2 dimensions based on Principal Component 1 and Principal Component 2 scores. Because 2 of the 13 traits measured in data set 1 and 3 of the 9 traits measured in data set 2 were taken from unreplicated plots, comparisons were made only between taxa rather than between individual accessions. The individual accessions provided replication for their respective taxa.

\section{Results and Discussion}

\section{Data set 1}

In the 25-day greenhouse trial, multisetus accessions emerged faster, had longer leaves at 10 days, and had greater total plant dry-matter at harvest than the other 2 taxa (Table 1). The faster seedling development of multisetus may relate to its prevalence in regions with relatively warm springs like the Columbia and Snake River Plains. Brevifolius emerged slowest, which may be because of the cooler springs and late freezes of the Rocky Mountains, a region where this taxon predominates. Elymoides had the least total plant dry-matter of the 3 taxa, probably 
because it is most common in the semiarid cold desert, a stressful environment where conservative growth is probably advantageous. Root-to-shoot ratio was least for brevifolius and greatest for elymoides. Evaporative demand, necessitating a greater root-to-shoot ratio, is typically greater in the semi-arid cold desert, where elymoides predominates, than in the Rocky Mountains, where brevifolius predominates. Brevifolius and elymoides were similar for leaf area and root length and lower than multisetus, which again may relate to the latter's prevalence in warmer regions. Brevifolius had lower specific leaf area, i.e., thicker leaves, than the other 2 taxa, but no differences among taxa were observed for specific root length. Likewise, Arredondo et al. (1998) found that 4 brevifolius accessions had lower specific leaf area than the multisetus, Sand Hollow. Low specific leaf area is associated with high carbon investment and long leaf life-span (Reich 1997), a characteristic of perennials relative to cheatgrass (Arredondo et al. 1998). We are uncertain as to whether brevifolius plants have greater longevity in their environments than do multisetus or elymoides plants.

In the field trial, elymoides headed earlier and produced seed with lower mass than the other taxa (Table 2), suggesting that it is adapted to regions lacking the summer precipitation that is found in the Rocky Mountains, for example. In the greenhouse depth-of-emergence trials, multisetus emerged significantly faster than brevifolius at both 20 and $60-\mathrm{mm}$ depths. The 25-day greenhouse trial also demonstrated the slow germination rate of brevifolius, based on emergence from a shallow 5-mm depth. Elymoides emergence was similar to multisetus and faster than brevifolius at $20 \mathrm{~mm}$, but lagged behind with brevifolius at $60 \mathrm{~mm}$. The low seed mass of elymoides accessions may have been a disadvantage at the deeper 60$\mathrm{mm}$ planting depth, while the high seed mass of brevifolius may have compensated for its inherently slow germinability at this depth. Correlations between seed mass and emergence index were negative $(r=$ $-0.50 ; \mathrm{P}<0.01)$ at $20 \mathrm{~mm}$ and positive ( $\mathrm{r}$ $=0.34 ; \mathrm{P}<0.10)$ at $60 \mathrm{~mm}$. Thus, largerseeded accessions emerged faster at 60 $\mathrm{mm}$, while the reverse was true at $20 \mathrm{~mm}$. Emergence indices at the 2 depths were uncorrelated across accessions $(\mathrm{P}>0.10)$.

Nitrate reductase activities were lower for brevifolius than the other 2 taxa (Table 2). In agronomic crops, high leaf nitrate reductase activity was correlated with increased plant growth and grain yield, especially at low $(<10 \mathrm{mM})$ external nitrate concentrations (Johnson et al. 1976, Feil et al. 1993). In addition, barley mutants with low nitrate reductase activity grew slower in the cool early-season and matured later than wild-type plants (Blackwood and Hallam, 1979). Measured nitrate reductase activity is the result of a complex interaction of nitrate, carbohydrate availability, plant development, and light. But plant materials with higher nitrate reductase activity, e.g., elymoides and multisetus, that can more effectively assimilate and compete for soil nitrogen may grow or become established faster than those with lower nitrate reductase activity, e.g., brevifolius. Indeed, the slow emergence of brevifolius from a 5-mm planting depth relative to elymoides and multisetus was noted above. Principal component loadings for days to emergence and nitrate reductase activity were negatively correlated for both principal components 1 and 2 , but the relationship was stronger for principal component 2 (Table 3 ).

Principal Components 1 and 2 explained 38 and $29 \%$ of the variation, respectively, among accessions for the 13 traits. Loadings for Principal Component 1 indicate that accessions with higher Principal Component 1 scores had generally more rapid emergence at a $5-\mathrm{mm}$ planting depth, greater day-10 leaf length, and greater total plant dry-matter, root-toshoot ratio, leaf area, and root length at
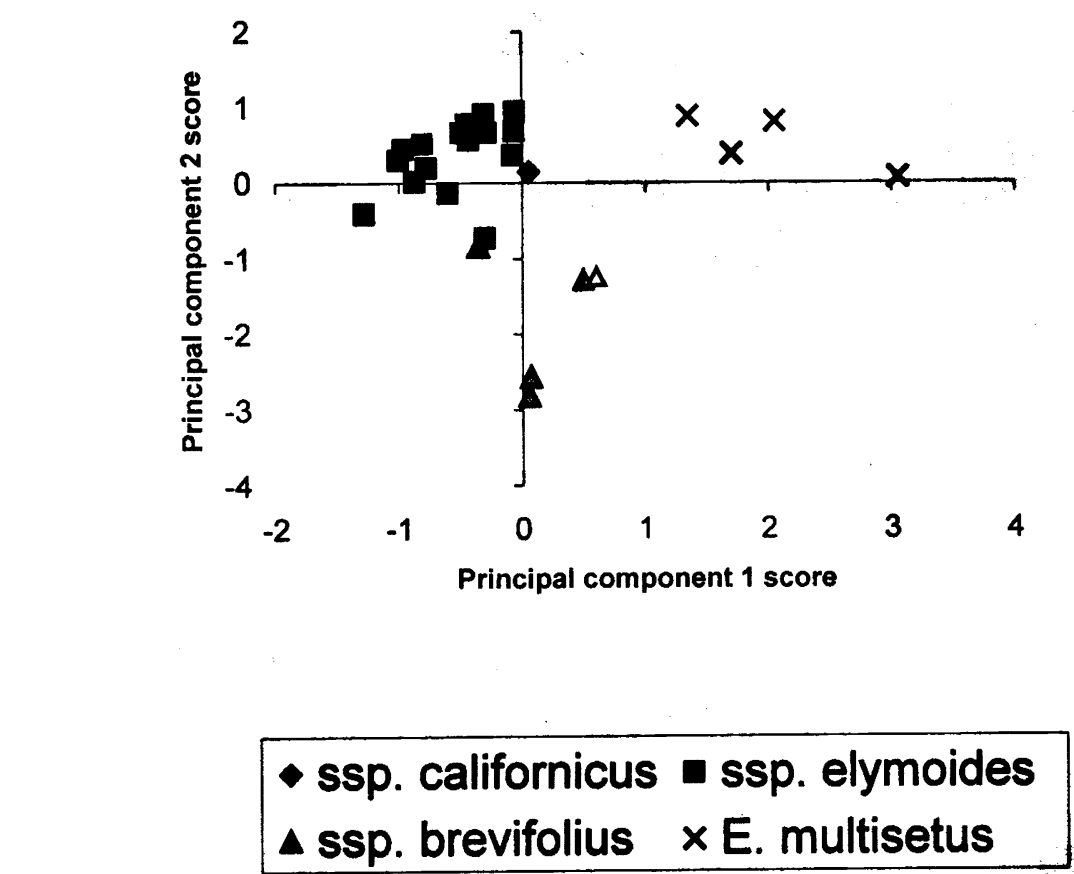

Fig. 1. Plot of the first 2 principal component scores for 27 Elymus elymoides and E. multisetus squirreltail accessions in data set 1. harvest in the greenhouse trial; later heading date and greater seed mass in the field; and more rapid emergence from a $60-\mathrm{mm}$ planting depth (Table 3). Principal Component 1 separated multisetus (high Brevifolius was intermediate between these 2, but closer to elymoides (Fig. 1). Loadings for Principal Component 2 indicate that accessions with higher Principal Component 2 scores had generally more depth; greater root-to-shoot ratio, greater specific leaf area (thinner leaves), and lower specific root length (thicker roots) at harvest in the greenhouse trial; earlier heading date and lower seed mass in the field; more rapid emergence from a 20$\mathrm{mm}$ planting depth; and higher nitrate reductase activity. Principal Component 2 separated elymoides and multisetus (high scores) from brevifolius (low scores). Overlap among the 3 taxa was absent in the 2-dimensional scatter plot, but beyond that, accessions did not appear to be organized in any geographical manner.

Values for the lone californicus accession, PI 531604, were within the range of elymoides accessions for all traits except total plant dry-matter in the greenhouse and seed mass in the field, where PI 531604 had slightly greater values (Tables 1, 2). Accession PI 531604 was clearly more similar to elymoides than to brevifolius or multisetus, supporting a close taxscores) from elymoides (low scores). rapid emergence at a $5-\mathrm{mm}$ planting 
Table 4 Means for 10 elymoides, 21 brevifolius, and 16 multisetus squirreltail accessions in data set 2 for 6 traits in a 34-day greenhouse trial.

\begin{tabular}{|c|c|c|c|c|c|c|c|c|}
\hline Taxon/ Accession & Collection location & Elevation & $\begin{array}{c}\text { Days to } \\
\text { emergence }\end{array}$ & $\begin{array}{c}\text { Leaf } \\
\text { length ( } 17 \\
\text { days post- } \\
\text { plant) }\end{array}$ & $\begin{array}{l}\text { Total plant } \\
\text { dry-matter }\end{array}$ & $\begin{array}{l}\text { Root-to- } \\
\text { shoot ratio }\end{array}$ & $\begin{array}{l}\text { Root } \\
\text { length }\end{array}$ & $\begin{array}{c}\text { Specific root } \\
\text { length }\end{array}$ \\
\hline & & $(\mathrm{m})$ & (no.) & $(\mathrm{mm})$ & $\left(\mathrm{mg} \mathrm{plant}^{-1}\right)$ & $\left(\mathrm{mg} \mathrm{mg}^{-1}\right)$ & $\left(\mathrm{mm} \mathrm{plant}^{-1}\right)$ & $\left(\mathrm{mm} \mathrm{mg}^{-1}\right)$ \\
\hline \multicolumn{9}{|l|}{ elymoides } \\
\hline $\mathrm{T}-1173$ & east of Mountain Home, Ida. & 1050 & 5.7 & 38 & 4.09 & 1.28 & 640 & 278 \\
\hline $\mathrm{T}-1174$ & west of Mountain Home, Ida. & 950 & 4.4 & 38 & 5.18 & 1.27 & 860 & 297 \\
\hline $\mathrm{T}-1175$ & Ditto Creek, Elmore Co., Ida. & 1000 & 4.6 & 42 & 4.58 & 1.01 & 720 & 313 \\
\hline $\mathrm{T}-1191$ & County Rd 10, Moffat Co., Colo. & 2150 & 5.0 & 41 & 5.36 & 1.16 & 870 & 302 \\
\hline $\mathrm{T}-1192$ & Point of Rocks, Sweetwater Co., Wyo. & 2200 & 4.7 & 47 & 5.69 & 1.39 & 1090 & 329 \\
\hline $\mathrm{T}-1193$ & Superior, Wyo. & 2200 & 5.9 & 37 & 4.04 & 1.68 & 730 & 289 \\
\hline $\mathrm{T}-1198$ & btwn Sage Junction \& Laketown, Ut. & 2200 & 5.0 & 42 & 4.47 & 1.27 & 840 & 336 \\
\hline $\mathrm{T}-1223$ & Fish Creek, Carey, Ida. & 1450 & 4.3 & 49 & 5.94 & 1.09 & 870 & 281 \\
\hline $\mathrm{T}-1224$ & Atomic City, Bingham Co., Ida. & 1500 & 4.5 & 49 & 5.26 & 1.35 & 770 & 255 \\
\hline PI 619553 & Shoshone, Ida. & 1300 & 4.8 & 38 & 5.29 & 1.20 & 780 & 270 \\
\hline mean & & 1633 & $4.9 b^{\#}$ & $42 \mathrm{~b}$ & $4.99 \mathrm{c}$ & $1.27 \mathrm{a}$ & $817 \mathrm{c}$ & $295 \mathrm{~b}$ \\
\hline \multicolumn{9}{|l|}{ brevifolius } \\
\hline $\mathrm{T}-1180$ & northeast of Wagonmound, N.M. & 2000 & 7.4 & 30 & 5.52 & 0.84 & 710 & 282 \\
\hline $\mathrm{T}-1233$ & north of Hermosa, Colo. & 2000 & 5.8 & 44 & 9.53 & 0.61 & 1210 & 335 \\
\hline $\mathrm{T}-1238$ & east of Chimney Rock, Colo. & 2050 & 5.8 & 44 & 8.89 & 0.50 & 970 & 327 \\
\hline $\mathrm{T}-1239$ & northeast of Pagosa Springs, Colo. & 2350 & 6.4 & 39 & 7.33 & 0.85 & 1160 & 345 \\
\hline $\mathrm{T}-1242$ & north of Lake City, Colo. & 2450 & 6.4 & 37 & 6.16 & 0.88 & 1060 & 367 \\
\hline $\mathrm{T}-1249$ & west of Sargents, Colo. & 2600 & 6.8 & 35 & 7.68 & 0.65 & 1080 & 356 \\
\hline $\mathrm{T}-1260$ & south of Westcliffe, Colo. & 2450 & 6.6 & 42 & 6.61 & 0.76 & 1060 & 372 \\
\hline $\mathrm{T}-1264$ & north of Colmor, N.M. & 1850 & 7.0 & 35 & 5.33 & 0.74 & 800 & 354 \\
\hline $\mathrm{T}-1265$ & north of Wagonmound, N.M. & 1900 & 7.1 & 37 & 5.56 & 0.82 & 980 & 392 \\
\hline $\mathrm{T}-1271$ & southwest of Ocate, N.M. & 2300 & 6.3 & 45 & 6.86 & 0.81 & 1050 & 342 \\
\hline $\mathrm{T}-1272$ & La Cueva, N.M. & 2200 & 6.4 & 43 & 5.46 & 0.92 & 850 & 326 \\
\hline $\mathrm{T}-1277$ & Tres Piedras, N.M. & 2350 & 6.6 & 44 & 5.70 & 0.91 & 1030 & 380 \\
\hline T-1299 & north of Flagstaff, Ariz. & 2150 & 6.2 & 47 & 8.44 & 0.76 & 1500 & 411 \\
\hline (mean) & & $(2204)$ & $(6.5)$ & $(40)$ & $(6.85)$ & $(0.77)$ & $(1035)$ & $(353)$ \\
\hline \multicolumn{9}{|l|}{ group B } \\
\hline $\mathrm{T}-1228$ & Colton, Ut. & 2150 & 6.5 & 37 & 3.70 & 1.31 & 910 & 433 \\
\hline T-1243 & north of Powderhorn, Colo. & 2750 & 6.3 & 39 & 5.10 & 1.07 & 1070 & 405 \\
\hline $\mathrm{T}-1308$ & northwest of Almont, Colo. & 2500 & 5.7 & 39 & 4.37 & 1.07 & 980 & 434 \\
\hline (mean) & & $(2467)$ & $(6.2)$ & $(38)$ & $(4.39)$ & $(1.15)$ & (987) & $(424)$ \\
\hline \multicolumn{9}{|l|}{ group $\mathrm{C}$} \\
\hline $\mathrm{T}-1202$ & hwy 75 X 20, Blaine Co., Ida. & 1350 & 5.4 & 42 & 4.71 & 1.26 & 720 & 274 \\
\hline $\mathrm{T}-1203$ & east of Fairfield, Ida. & 1500 & 5.4 & 52 & 6.28 & 0.84 & 1060 & 369 \\
\hline $\mathrm{T}-1204$ & east of Hill City, Ida. & 1550 & 5.8 & 43 & 6.55 & 1.17 & 1010 & 286 \\
\hline $\mathrm{T}-1205$ & west of Hill City, Ida. & 1600 & 4.2 & 44 & 5.92 & 1.26 & 1080 & 327 \\
\hline $\mathrm{T}-1206$ & east of Dixie, Elmore Co., Ida. & 1600 & 5.0 & 45 & 5.92 & 1.18 & 1080 & 336 \\
\hline (mean) & & $(1520)$ & $(5.2)$ & $(45)$ & $(5.88)$ & $(1.14)$ & $(990)$ & $(319)$ \\
\hline mean & & 2100 & $6.1 \mathrm{a}$ & $41 \mathrm{~b}$ & $6.27 \mathrm{~b}$ & $0.91 \mathrm{~b}$ & 1018 b & 355 a \\
\hline \multicolumn{9}{|l|}{ multisetus } \\
\hline PI 619454 & A-line canal, Gem Co., Ida. & 950 & 3.9 & 61 & 10.49 & 1.14 & 1660 & 297 \\
\hline PI 619456 & Cartwright Rd., Ada Co., Ida. & 1000 & 4.1 & 49 & 9.00 & 1.17 & 1560 & 321 \\
\hline PI 619457 & Little Land \& Livestock, Canyon Co., Ida. & 800 & 3.8 & 64 & 9.91 & 1.22 & 1360 & 250 \\
\hline PI 619458 & northwest of Mayfield, Elmore Co., Ida. & 1100 & 4.0 & 51 & 9.92 & 1.31 & 1470 & 262 \\
\hline PI 619459 & Boise, Ida. & 1000 & 3.9 & 55 & 9.21 & 1.20 & 1530 & 305 \\
\hline PI 619460 & Bogus Basin Rd., Ada Co., Ida. & 1000 & 4.3 & 53 & 9.05 & 1.16 & 1510 & 311 \\
\hline PI 619461 & Barber, Ida. & 950 & 3.9 & 51 & 9.24 & 1.16 & 1390 & 280 \\
\hline PI 619462 & southeast of Mayfield, Elmore Co., Ida. & 1100 & 3.7 & 58 & 8.74 & 1.39 & 1360 & 267 \\
\hline PI 619463 & Ditto Creek, Elmore Co., Ida. & 1000 & 3.9 & 55 & 9.17 & 1.34 & 1490 & 284 \\
\hline PI 619464 & Lower Hatley, Canyon Co., Ida. & 800 & 3.8 & 56 & 9.61 & 0.99 & 1280 & 268 \\
\hline PI 619465 & Seaman's Gulch Rd., Ada Co., Ida. & 1000 & 4.4 & 53 & 9.87 & 1.23 & 1510 & 278 \\
\hline PI 619467 & Middle Hatley, Gem Co., Ida. & 800 & 4.3 & 52 & 8.25 & 1.07 & 1160 & 272 \\
\hline PI 619564 & Ditto Creek, Elmore Co., Ida. & 1100 & 4.9 & 44 & 7.38 & 1.04 & 1030 & 273 \\
\hline $\mathrm{T}-1165$ & King Hill, Ida. & 850 & 4.3 & 63 & 10.87 & 1.25 & 1610 & 267 \\
\hline $\mathrm{T}-1183$ & Mountain Home, Ida. & 1000 & 4.2 & 65 & 10.26 & 0.99 & 1380 & 270 \\
\hline $\mathrm{T}-1214$ & Black's Creek, Ada Co., Ida. & 1100 & 4.2 & 49 & 7.99 & 1.04 & 1200 & 294 \\
\hline mean & & 950 & $4.1 \mathrm{c}$ & 55 a & $9.31 \mathrm{a}$ & $1.17 \mathrm{a}$ & 1406 a & $281 \mathrm{~b}$ \\
\hline
\end{tabular}

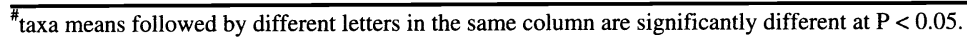


onomic relationship between californicus and elymoides, as favored by Wilson (1963).

\section{Data set 2}

In the greenhouse trial, multisetus emerged faster, had longer leaves at 17 days, and had greater total plant dry-matter at harvest than the other 2 taxa (Table 4). Brevifolius emerged most slowly from a 5-mm planting depth and elymoides had the least total plant dry-matter. Root-toshoot ratio was least for brevifolius and greater for multisetus and elymoides. Specific root length was greater for brevifolius (thin roots), especially group B (see below), than for multisetus or elymoides. Multisetus had the greatest root length with brevifolius intermediate and elymoides least. In the field trial (Table 5), elymoides had the earliest heading date, the lowest seed mass, and the shortest height. Brevifolius and multisetus did not differ from one another for these traits.

The first 2 principal components explained 41 and $40 \%$ of the variation, respectively, among accessions for the 9 traits. Loadings for Principal Component 1 indicate that accessions with high Principal Component 1 scores had generally greater total plant dry-matter, lower root-to-shoot ratio, and greater root length at harvest in the greenhouse trial; and later heading date, greater height, and greater seed mass in the field (Table 3). Principal Component 1 separated brevifolius and multisetus (high scores) from elymoides (low scores) (Fig. 2). Loadings for Principal Component 2 indicate that accessions with higher Principal Component 2 scores had generally more rapid emergence at a $5-\mathrm{mm}$ planting depth; greater leaf length on day 17 and greater total plant dry-matter, greater root length, and lower specific root length (thicker roots) at harvest in the greenhouse trial. Principal Component 2 separated multisetus (high scores) from elymoides and brevifolius (low scores). This separation resulted in plots that oriented the 3 taxa in a similar manner to data set 1 (Fig. 1). Variation among accessions was greater for brevifolius than the other 2 taxa; this was reflected mostly by Principal Component 1 scores.
Together, Principal Components 1 and 2 separated brevifolius accessions into 3 groups (Fig. 2). "Group A" accessions were late-maturing with high-seed mass and originated from medium to high elevations (1850 to $2600 \mathrm{~m}$ ) in Colorado, New Mexico, and Arizona. "Group B" accessions were early-maturing (as early as elymoides) with low-seed mass and originated from high elevations (2150 to $2750 \mathrm{~m}$ ) in Colorado and Utah. "Group C" accessions were intermediate-maturing with low-seed mass and originated from low to medium elevations (1350 to 1600 $\mathrm{m})$ in southern Idaho. Amplified fragment length polymorphisms (AFLP), a DNA marker technique, have verified that these 3 groups are genetically distinct (Larson et al. 2003).

In the greenhouse (Table 4), days to emergence were generally lesser for Group $\mathrm{C}$ accessions and more similar to elymoides than were Group A or B accessions. Total plant dry-matter was generally greatest for Group A accessions, least for Group B accessions, and intermediate for Group $C$ accessions. Root-to-shoot ratio

Table 5. Means for 10 elymoides, 21 brevifolius, and 16 multisetus squirreltail accessions in data set 2 for 6 traits in a 2-year field trial.

\begin{tabular}{|c|c|c|c|c|c|c|c|}
\hline $\begin{array}{l}\text { Taxon/ } \\
\text { Accession }\end{array}$ & $\begin{array}{l}\text { Heading } \\
\text { date }\end{array}$ & $\begin{array}{c}\text { Plant } \\
\text { height }\end{array}$ & $\begin{array}{l}\text { Seed } \\
\text { mass }\end{array}$ & $\begin{array}{c}\text { Taxon/ } \\
\text { Accession }\end{array}$ & $\begin{array}{l}\text { Heading } \\
\text { date }\end{array}$ & $\begin{array}{l}\text { Plant } \\
\text { height }\end{array}$ & $\begin{array}{l}\text { Seed } \\
\text { mass }\end{array}$ \\
\hline & (days after $4 / 30$ ) & (m) & $\left(\mathrm{mg} \mathrm{seed}^{-1}\right)$ & & ys after $4 / 30$ ) & (m) & $\left(\mathrm{mg} \mathrm{seed}^{-1}\right)$ \\
\hline elymoides & & & & brevifoli & & & \\
\hline $\mathrm{T}-1173$ & 21 & 0.28 & 2.21 & group $\mathrm{A}$ & & & \\
\hline $\mathrm{T}-1174$ & 21 & 0.32 & 2.37 & $\mathrm{~T}-1180$ & 60 & 0.66 & 4.81 \\
\hline $\mathrm{T}-1175$ & 22 & 0.31 & 2.16 & $\mathrm{~T}-1233$ & 62 & 0.64 & 4.51 \\
\hline $\mathrm{T}-1191$ & 18 & 0.28 & 3.29 & $\mathrm{~T}-1238$ & 47 & 0.75 & 5.10 \\
\hline T-1192 & 20 & 0.27 & 2.83 & $\mathrm{~T}-1239$ & 49 & 0.75 & 5.34 \\
\hline $\mathrm{T}-1193$ & 15 & 0.38 & 2.36 & $\mathrm{~T}-1242$ & 42 & 0.77 & 5.36 \\
\hline T-1198 & 20 & 0.48 & 2.91 & $\mathrm{~T}-1249$ & 46 & 0.68 & 5.71 \\
\hline $\mathrm{T}-1223$ & 26 & 0.42 & 3.01 & $\mathrm{~T}-1260$ & 51 & 0.53 & 4.58 \\
\hline $\mathrm{T}-1224$ & 24 & 0.42 & 2.73 & $\mathrm{~T}-1264$ & 65 & 0.71 & 4.86 \\
\hline \multirow[t]{2}{*}{ PI 619553} & 23 & 0.38 & 3.05 & $\mathrm{~T}-1265$ & 60 & 0.71 & 5.02 \\
\hline & & & & $\mathrm{T}-1271$ & 57 & 0.72 & 5.23 \\
\hline \multirow[t]{2}{*}{ mean } & $21 \mathrm{~b}$ & 0.35 b & $2.69 \mathrm{~b}$ & $\mathrm{~T}-1272$ & 57 & 0.72 & 5.48 \\
\hline & & & & $\mathrm{T}-1277$ & 53 & 0.63 & 4.51 \\
\hline multisetus & & & & T-1299 & 63 & 0.66 & 6.16 \\
\hline PI 619454 & 44 & 0.53 & 4.88 & (mean) & (55) & $(0.68)$ & (5.13) \\
\hline PI 619456 & 42 & 0.58 & 5.50 & & & & \\
\hline PI 619457 & 42 & 0.58 & 4.72 & group B & & & \\
\hline PI 619458 & 42 & 0.68 & 5.83 & T-1228 & 23 & 0.51 & 3.39 \\
\hline PI 619459 & 41 & 0.53 & 5.05 & $\mathrm{~T}-1243$ & 24 & 0.53 & 3.77 \\
\hline PI 619460 & 42 & 0.58 & 5.01 & $\mathrm{~T}-1245$ & 17 & 0.58 & 3.37 \\
\hline PI 619461 & 41 & 0.64 & 5.18 & (mean) & (21) & $(0.54)$ & $(3.51)$ \\
\hline PI 619462 & 45 & 0.65 & 5.07 & & & & \\
\hline PI 619463 & 45 & 0.57 & 4.72 & group C & & & \\
\hline PI 619464 & 44 & 0.63 & 4.87 & $\mathrm{~T}-1202$ & 34 & 0.50 & 3.75 \\
\hline PI 619465 & 42 & 0.61 & 5.14 & $\mathrm{~T}-1203$ & 32 & 0.54 & 3.74 \\
\hline PI 619467 & 42 & 0.56 & 4.62 & T-1204 & 34 & 0.58 & 4.61 \\
\hline PI 619564 & 42 & 0.66 & 4.87 & $\mathrm{~T}-1205$ & 38 & 0.62 & 3.47 \\
\hline $\mathrm{T}-1165$ & 33 & 0.53 & 4.15 & $\mathrm{~T}-1206$ & 38 & 0.60 & 3.27 \\
\hline $\mathrm{T}-1183$ & 41 & 0.62 & 5.39 & (mean) & (35) & $(0.57)$ & (3.77) \\
\hline \multirow[t]{2}{*}{$\mathrm{T}-1214$} & 41 & 0.60 & 5.49 & & & & \\
\hline & & & & mean & $45 a$ & 0.64 a & $4.57 \mathrm{a}$ \\
\hline mean & $42 a$ & 0.59 a & $5.03 \mathrm{a}$ & & & & \\
\hline
\end{tabular}

\#taxa means followed by different letters in the same column are significantly different at $\mathrm{P}<0.05$. 


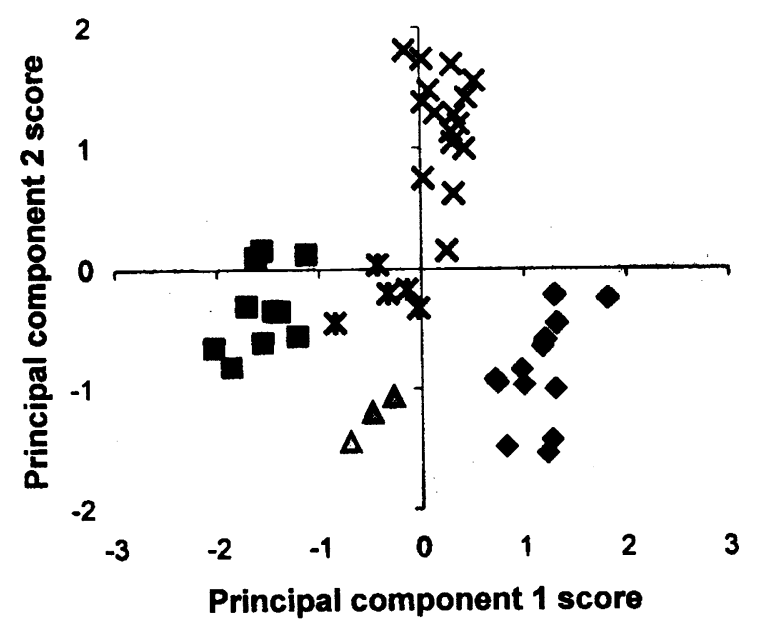

\section{- ssp. brevifolius (A) I ssp. elymoides $\Delta$ ssp. brevifolius (B) $\times$ E. multisetus * ssp. brevifolius (C)}

Fig. 2. Plot of the first 2 principal component scores for 47 Elymus elymoides and E. multisetus squirreltail accessions in data set 2.

was generally lower for Group A accessions than Group B or C accessions, which were more similar to elymoides and multisetus. Specific root length was generally greater for Group B accessions than Group A or $\mathrm{C}$ accessions, which were more similar to elymoides and multisetus. In the field trial (Table 5), seed mass was generally greater for Group A accessions, which were more similar to multisetus, than Group B or C accessions, which were more similar to elymoides. Plant height was generally greater for Group A accessions than Group B or C accessions, which were more similar to multisetus, which in turn was greater than elymoides.

While the geographical range of Group $\mathrm{C}$ is clearly separate from Groups $\mathrm{A}$ and B, Groups A and B themselves are overlapping and may occur as biotypes at the same site. Accession T-1245, a group B accession originating northwest of Almont, Colo., was collected at the same site as T-1308, which was not included in data set 2 , but has been confirmed as a Group A accession based on its AFLP profile (Larson et al. 2003). Likewise, T1264, a Group A accession originating north of Colmor, N.M., was collected from the same site as T-1309, also not included in data set 2 . Based on its early maturity (unpublished data), however, T1309 is likely a Group B accession.

Relative to Group A, Group B is earlier in maturity, is shorter, and has greater root-to-shoot ratio, greater specific root length (thinner roots), lower total plant dry-matter, and lower seed mass. We wonder whether some or all of these traits may be associated with adaptation to higher elevations. In fact, T-1243 (Powderhorn, Colorado), a Group B accession, was collected at $2,750 \mathrm{~m}$, the highest elevation of any accession. While our elevation data (Table 4) do not directly support this speculation, we may have missed a trend by failing to collect at higher elevations than we did.

\section{Conclusions}

In both data sets, the 3 squirreltail taxa were easily separated by the traits examined. Data set 1 had 13 traits and data set 2 had 9 traits. The 8 traits in common to both data sets were days to emergence from $5 \mathrm{~mm}$; leaf length (at 10 days in data set 1 and 17 days in data set 2), total plant dry-matter, root-to-shoot ratio, root length, and specific root length at harvest; heading date; and seed mass. In addition to the 8 traits in common, data set 1 included leaf area, specific leaf area, days to emergence from $20 \mathrm{~mm}$, days to emergence from $60 \mathrm{~mm}$, and nitrate reductase activity. In addition to the 8 traits in common, data set 2 included plant height. With 1 exception (root-to-shoot ratio) the 2 data sets ranked the taxa in the same order for all 8 common traits. However, for 3 of these traits (root-to-shoot ratio, root length, and specific root length), significant differences among taxon means were slightly different. For root-to-shoot ratio, data set 1 grouped middle-ranking elymoides with lowest-ranking breviolius, while data set 2 grouped highest-ranking elymoides with middle-ranking multisetus. For root length, data set 1 grouped lowestranking elymoides with middle-ranking brevifolius, while data set 2 grouped lowest-ranking elymoides apart from middleranking brevifolius. For specific root length, data set 1 grouped all 3 taxa together, while data set 2 separated highest-ranking brevifolius apart from elymoides and multisetus.

Of all taxa, elymoides was the earliest, shortest, and had the lowest seed mass, seedling dry-matter, and root length. Brevifolius had the lowest root-to-shoot ratio, specific leaf area, and nitrate reductase activity, the highest specific root length, and generally the slowest emergence from a normal planting depth. Low specific leaf area is associated with high carbon investment and great leaf life-span (Reich 1997). Multisetus had the fastest emergence from a normal planting depth, longest leaf length at 10 days (data set 1) or 17 days (data set 2) post-plant, and greatest seedling dry-matter, leaf area, and root length.

Wilson (1963) stated that brevifolius displays the greatest ecological diversity of the 5 squirreltail taxa, being found in desert to montane habitats from 600 to $3000 \mathrm{~m}$ elevation and with extreme variation in size. Variation among accessions was similar for the 3 taxa in data set 1 , but brevifolius had the greatest variation in data set 2, perhaps because these brevifolius accessions represented a wider geographical distribution than the other 2 taxa. Nevertheless, we found a greater degree of discontinuity, e.g., Groups A, B, and $\mathrm{C}$, within brevifolius than within $\mathrm{mul}$ tisetus or elymoides. In data set 2 , accessions that plotted near the convergence of the 3 taxa were from the environs of southern Idaho, a region with ample representation of all 3 taxa. Overall, Group C accessions were more similar to elymoides and multisetus than were Group A or B accessions (Fig. 2).

Five brevifolius accessions in data set 1 can be reinterpreted based on findings of data set 2 and subsequent AFLP analysis (Larson et al. 2003). Three late-maturing, 
high seed-mass accessions, 9040189, 904187, and PI 531605, qualify as Group A, according to AFLP data. While no AFLP data have been collected on the fourth accession, Acc:1123, it appears to be a member of Group $C$ based on its Oregon origin, fast emergence (Table 1) and low seed mass (Table 2). It should be noted, however, that its heading date is similar to the 3 Group A accessions. The fifth accession, Acc:1130 (Savageton, Wyo.), is unique in this study. Based on AFLP results, it belongs to "Group D", accessions of which we have collected on the High Plains from Alberta to Colorado.

Our data support the recognition of elymoides, brevifolius, and multisetus taxa, but they do not provide direction as to whether each merits specific or subspecific rank. From an ecological perspective, these data do not support the suggestion that any one pair of elymoides, multisetus, and brevifolius is more similar than any other pair. Furthermore, these results provide guidance as to which specific commercially available plant materials should be planted in which locations. For example, the 3 distinct groups of brevifolius accessions, as well as the different taxa, are ecologically distinct and are likely adapted to regions in which their particular group is found in nature. These results reflect the highly ecotypic nature of the squirreltails.

\section{Literature Cited}

Arnow, L.A. 1993. Gramineae A.L. Juss. p 775-833. In: S.L. Welsh, N.D. Atwood, S. Goodrich, and L.C. Higgins (eds.) A Utah flora. $2^{\text {nd }}$ ed. Brigham Young Univ., Provo, Ut.

Arredondo, J.T., T.A. Jones, and D.A. Johnson. 1998. Seedling growth of Intermountain perennial and weedy annual grasses. J. Range Manage. 51:584-589.

Berntson, G.M. 1992. A computer program for characterizing root systems branching pattern. Plant Soil 140:145-149.

Barkworth, M.E., D.R. Dewey, and R.J. Atkins. 1983. New generic concepts in the Triticeae of the Intermountain Region: Key and comments. Great Basin Natur. 43:561-572.

Blackwood, G. and R. Hallam. 1979. Nitrate reductase activity in wheat (Triticum aes tivum L.) II. The correlation with yield. New Phytol. 82:417-425.

Feil, B., R. Thiraporn, and P. Stamp. 1993. In vitro nitrate reductase activity of laboratory-grown seedlings as an indirect selection criterion for maize. Crop Sci. 33:1280-1286.

Hitchcock, A.S. 1950. Manual of the grasses of the United States. $2^{\text {nd }}$ ed. (rev. A. Chase). USDA Misc. Publ. No. 200. U.S. Govt. Print. Office. Washington, D.C.

Holmgren, A.H. and N.H. Holmgren. 1977. Poaceae. p. 175-464. In: A. Cronquist, A.H. Holmgren, N.H. Holmgren, J.L. Reveal, and P.K. Holmgren (eds.) Intermountain flora. vol. 6. Columbia Univ. Press, New York.
Jensen, K.B., Y.F. Zhang, and D.R. Dewey. 1990. Mode of pollination of perennial species of the Triticeae in relation to genomically defined genera. Can. J. Plant Sci. 70:215-225.

Johnson, C.B., W.J. Whittington, and G.C. Blackwood. 1976. Nitrate reductase as a possible predictive test of crop yield. Nature 262:133-134.

Kaiser, H.F. 1958. The varimax criterion for analytic rotation in factor analysis. Psychometrika 23:187-200.

Larson, S.R., T.A. Jones, C.L. McCracken, and K.B. Jensen. 2003. Amplified fragment length polymorphism in E. elymoides, $E$. multisetus, and other Elymus taxa. Can. J. Bot. 81 (in press).

Maguire, J.D. 1962. Speed of germination aid in selection and evaluation of seedling emergence and vigor. Crop Sci. 2:176-177.

Morrison, D.F. 1976. Multivariate statistical methods. $2^{\text {nd }}$ ed. McGraw-Hill Book Co., New York, N.Y.

Redinbaugh, M.G. and W.H. Campbell. 1985. Adaptation of the dye-binding protein assay to microtiter plates. Anal. Biochem. 147:144-147.

Redinbaugh, M.G., S.W. Ritchie, K.W. Hendrix, C.T. Mackown, and W.H. Campbell. 1996. Expression of enzyme activities and transcripts required for nitrate assimilation in maize (Zea mays L. A188 X BMS) suspension cell cultures. Plant Sci. 119:169-181.

Reich, P.B. 1997. From tropics to tundra: Global convergence in plant functioning. Proc. Nat. Acad. Sci. USA 94:13730-13734.

Wilson, F.D. 1963. Revision of Sitanion (Triticeae, Gramineae). Brittonia 15:303-323. 